\title{
Groundwater Storage Change Estimation Using Combination of Hydrogeophysical and Groundwater Table Fluctuation Methods in Hard Rock Aquifers
}

\author{
Mahamadou Koïta ${ }^{1, *}$, Hamma Fabien Yonli ${ }^{2}$ [D , Donissongou Dimitri Soro ${ }^{1}$, \\ Amagana Emmanuel Dara ${ }^{1}$ (D) and Jean-Michel Vouillamoz ${ }^{3}$ \\ 1 Institut International d'Ingénierie de l'Eau et de l'Environnement, Rue de la science, 01 BP 594 \\ Ouagadougou, Burkina Faso; dimitri.soro@gmail.com (D.D.S.); emmanueldara36@gmail.com (A.E.D.) \\ 2 Ecole Nationale Supérieure d'Ingénieurs-Fada/Université Ouaga I Professeur Joseph Ki Zerbo, 94, rue 28-09, \\ 01 BP 6689 Ouagadougou, Burkina Faso; fabienyonli@yahoo.fr \\ 3 The Institute for Geosciences and Environmental research (IGE), University Grenoble Alpes, IRD, CNRS, \\ Grenoble INP, CS407000, 38058 Grenoble CEDEX 9, France; jean-michelvouillamoz@ird.fr \\ * Correspondence: mahamadou.koita@2ie-edu.org or kmahamoudk@yahoo.fr; Tel.: +226-70-67-21-39
}

Received: 15 November 2017; Accepted: 4 January 2018; Published: 6 January 2018

\begin{abstract}
This study aims to estimate the groundwater storage change of hard rock aquifers in the face of change. For this, the approach developed consisted initially in the implementation of 5 Magnetic Resonance Soundings (MRS) around the observation wells realized and monitored from 2014 to 2015 in the Sanon experimental site. In a second step, we determined the storage change using the MRS data and the water table fluctuation method. The MRS data show that the water content varies spatially from 4.5 to $1.3 \%$. The maximum value is recorded at the central valley where a piezometric dome is observed. The specific yield varies from $2.4 \%$ in the central valley to $1.3 \%$ at the outlet. The renewed water resource is estimated at $116 \mathrm{~mm}$ in the central valley and $32 \mathrm{~mm}$ at the outlet, which corresponds respectively to 13 and 3\% of the annual rainfall. The renewed water resource is consistent with the annual recharge. Thus, the combination of the MRS geophysical approach and water table fluctuation method is an efficient, fast and cheaper (compared with long-term pumping test) tool for the estimation of groundwater storage changes.
\end{abstract}

Keywords: change of groundwater stock; hard rock aquifer; specific yield; MRS sounding; water table fluctuation; Sanon catchment; Burkina Faso

\section{Introduction}

Groundwater resources in hard rocks play a major role in the water supply of millions of people in Africa. Thousands of boreholes are drilled in hard rocks in Africa. The high amount of almost dry holes (typically ranging between 25 and 60\%) confirms the complexity of hard rock aquifers which is controlled by several factors and it did not allow the African population to use groundwater resources for irrigation and drinking water when rain and surface water are lacking. In terms of food security, only 1.5 to $3 \%$ of African rural population use groundwater to irrigate [1]. In arid and semi-arid areas, groundwater offers several advantages over surface water (e.g., groundwater is less vulnerable to pathogenic contamination avoiding the expense and management of sophisticated treatment systems, its development is cheaper and can be scaled to allow in-field application on demand). In recent decades, the countries of Sahelian regions face several challenges in relation to the availability and exploitation of water resources (high population growth, rapid urbanization, economic pressures and climate change). Faced with such a situation, groundwater resources whose vulnerability to drought is low [2] seem to be the best alternative to respond to this emergency and adaptation to the impacts 
of changes and climatic variability. Thus, the appropriate supply of populations from this resource would significantly increase the resilience of rural populations to climate variability [3]. Unfortunately, groundwater is commonly excluded from current assessments of the impacts of historical and projected climate variability and change on water resources. This omission is of particular concern in Africa, where current usage and future adaptations in response to climate change and rapid population growth place considerable reliance upon groundwater to meet domestic, agricultural and industrial water demands [2]. However, despite growing dependency upon groundwater for urban water supplies some issues remain over the sustainability of these supplies, in terms not only of the magnitude of abstraction but also their quality. Estimates of groundwater storage are needed for quantifying groundwater resources [4] and for assessing the impact of climate and land-use changes on water resources [5]. Indeed, the amount of water stored in the rock reservoir plays a major role in the transient response of the aquifer to conditions that vary over time. The greater the groundwater storage, the higher the buffering capacity of the aquifer (all else being equal) and the slower the impact of changes caused by variation in pumping, recharge, or evapotranspiration (i.e., climatic and anthropogenic changes).

Prospecting of groundwater resources in hard rock has evolved considerably with many methods based on common Electromagnetic (EM) and/or Direct Current (DC) resistivity methods [6]. Although these methods make it possible to identify zones that are potentially favourable for wells siting according to the description of the structure and the geometry of the aquifers, well productivity is not guaranteed. It could be if the volume of water stored and the ease (permeability) with which it flows into the aquifer were known particularly at the location identified for drilling. Most of the studies on regional groundwater resources use large-scale indicators that are not suitable for accounting for local heterogeneity of hard rock [7]. At the local scale, most of the studies focus on well productivity (i.e., the volume of water that can be temporarily pumped) but do not take into account the amount of water stored in the rock reservoir and of its change although the latter is a fundamental parameter that controls the capacitive behaviour of the system and the long-term productivity of the borehole. The lack of data on the aquifer storage change in the hard rock aquifers area limits the study of the impact of climate change on groundwater. The estimation of the storage change in hard rock aquifers in the face of change requires the prior estimation of a fundamental property of the aquifer which is the storage. Indeed, many studies [8-10] have attempted to study the potential role played by the storage in hard rock under different climatic stress conditions through the development of complex geological conceptual models in transient state. The use of such models is essential both for predicting the impending impacts of climate change, testing and evaluating alternative resource management strategies. But unfortunately, from a practical point of view, their application has been largely limited to simple scenarios in a relatively steady state regime that conveniently ignores the essential role played by the storage of the aquifer when the water budget is not balanced. From different methods that exist to apprehend the storage of an aquifer, pumping tests are the common used. However, their implementation is limited by problems of cost, time because it requires the execution and equipment of wells (pumping and wells) and the implementation of a long-term pumping. Recently, many authors [11-14] proposed methodologies for regionalizing specific yield at the watershed scale. These methods combine at cell scale (pumping scale) water-table fluctuation and groundwater-budget techniques in the absence of recharge from rainfall, an aggregation method and variogram based statistics and kriging techniques. While these methods appear to be robust but require a great deal of geological, geophysical and hydrodynamic field investigation and require the availability of a number of existing wells or boreholes.

Some authors have considered estimating hydrodynamic parameters by other methods: notably from logging and geoelectrical measurements $[15,16]$. However, these methods are not directly "sensitive" to water and whether pumping tests or other methods, it remains impossible to access knowledge of the hydrodynamism before drilling. As a result, the hard rock environments remain 
poorly known or at least insufficiently and the boreholes are realized with a relative lack of knowledge of their ability to be productive and sustainable.

Recent developments in the magnetic resonance sounding (MRS) method seem particularly well suited to the description of aquifers since it measures a signal directly emitted by the hydrogen nuclei of water molecules [17-19] and provide more direct link to hydrogeological properties. The estimation of groundwater storage by this non-invasive method becomes thus a challenge. Advances in the parameterization of hydrogeological data from MRS data have been recently done on hard rock aquifers in Benin, in West Africa by Vouillamoz et al. [19]. These authors were able to establish from MRS a relationship between MRS water content and hydrogeological storage (specific yield). From this empirical relationship, the present study proposes a combined methodology of water table fluctuation and MRS in order to estimate the groundwater storage change in hard rock in the face of change. For this, the experimental site of Sanon whose geology is representative of that of West Africa is chosen as a case study. We initially performed five (05) MRS measurements around existing observation wells and on crests in the Sanon catchment. Secondly, we follow from 2014 to 2016 the water table fluctuation at observation wells around which the MRS measurements were performed. Finally, we compute groundwater storage change using the empirical relationship provided by Vouillamoz et al. [19], MRS data and water table fluctuation.

\section{Study Site}

The Sanon experimental site (Figure 1) is located approximately $40 \mathrm{~km}$ Northwest of Ouagadougou (the capital city of Burkina Faso). It covers an area of $14 \mathrm{~km}^{2}$. The relief consists of a broad, relatively flat-bottomed valley (elevation about $340 \mathrm{~m}$ a.s.l.) surrounded by rather flat lateritic ridges mainly covered by iron crust and elevation between 350 and $370 \mathrm{~m}$ a.s.l. The valley drains surface water westwards during the rainy season into the rivers.

Local geology of the study site is characterized by a patchwork of migmatite, gneiss and granite in the central valley and green rock at the ridges. There is no rock outcropping, which does not militate in favour of a precise mapping of the geological formations. Information on the geology of the site comes from the numerous drilling campaigns carried out during rural supply programs part of village water programs and research projects carried out in the Sanon village [20,21]. The analysis of the lithologs from drilling shows a predominance of granito-gneissic or even migmatic formations with intercalations of amphibolites (green rocks) [21]. The bedrock is covered by a mantle of alterites of a few tens of meters (about $25 \mathrm{~m}$ in the western part, 30 to $50 \mathrm{~m}$ in the valley) composed of lateritic cuirass, sandy clayey and grained arena overlying the fractured layer (that is also belonging to the weathering profile).

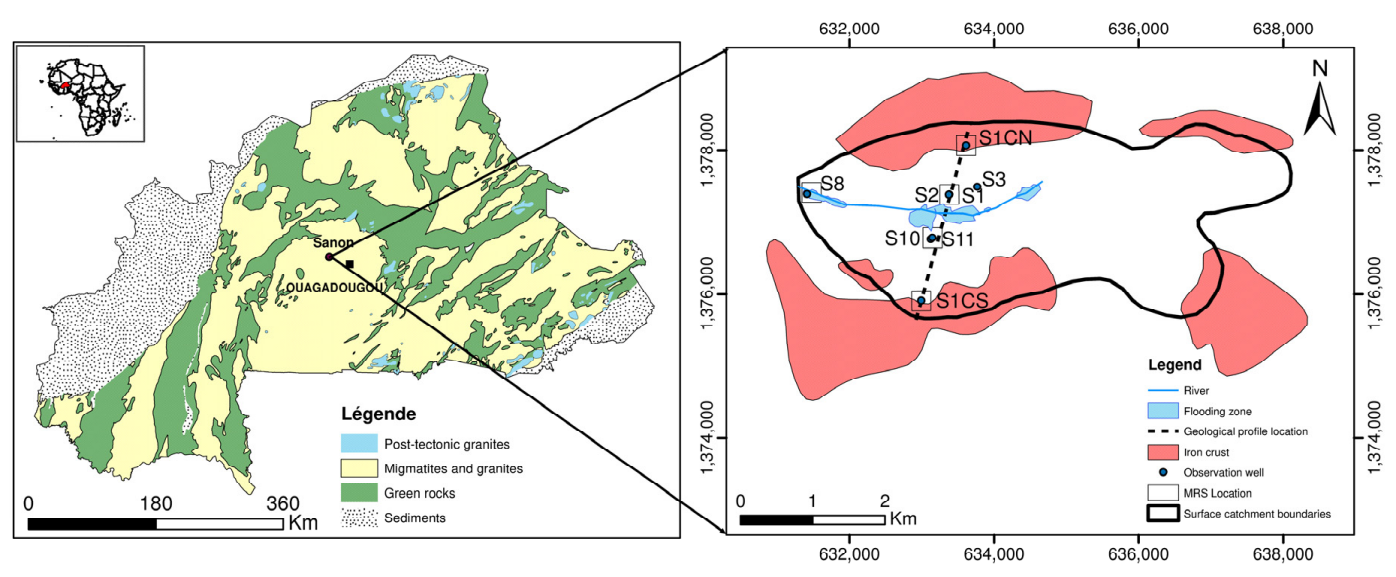

Figure 1. Location of the experimental catchment of Sanon showing the observation wells and MRS implementation sites. 
The description of the Sanon aquifer based on the geological model (from ridge to ridge) proposed by Soro et al. [22] (Figure 2) presents a classical vertical structuring [23]. The weathering profile (Figure 2) includes from the top to the bottom: the presence of four layers corresponding to the classical conceptual model for hard rocks, namely alloterite and isalterite layers which together form the "saprolite" a weathered fissured layer and the unweathered basement. The thickness of saprolite varies considerably on the site; it reaches its maximum mean value of $50 \mathrm{~m}$ in the central valley and its smallest value of approximately $30 \mathrm{~m}$ towards the ridges where it is covered with the lateritic iron crust whose thickness can reach sometimes ten meters. The fissured layer is characterized by numerous water strikes observed during the drilling. This layer is of a small thickness at the central valley (10 to $15 \mathrm{~m}$ ). It increases towards the ridges. The unweathered basement is locally fractured with the presence of conductive fractures probably of tectonic origin recorded during drilling.

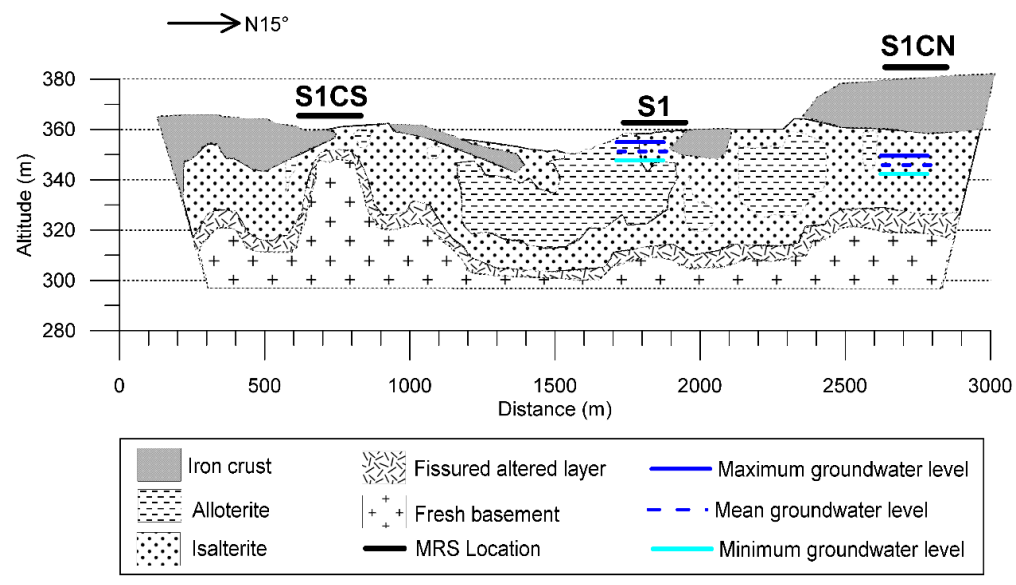

Figure 2. 2D geological conceptual model from ridge to ridge passing through the observation wells S1CN and S1 and showing the MRS implementation sites (modified, from Soro et al. [22]).

The hydrogeology of the site is strongly influenced by the structure and the geometry of the aquifer [19] the water table is shallow ( 8 to $10 \mathrm{~m}$ ) and is strongly influenced by climatic variations [21]. The aquifer shows a piezometric dome in the central valley, where the maximum recharge is observed below some temporary ponds. The Sanon site is equipped with many wells that are used for water table fluctuation monitoring and pumping tests.

\section{Materials and Methods}

The estimation of the change of groundwater storage in Sanon catchment is both based on hydrogeophysical MRS investigations and water table fluctuation monitoring. The interest of the coupling of these two approaches lies in the fact that from the empirical law proposed by Vouillamoz et al. [19] MRS data will enable estimating the specific yield of the aquifer. Once estimated, the value of the specific yield is used with the water table fluctuation method to estimate the change of groundwater storage. To validate the replicability of the empirical law found in Benin to Sanon site, we have compared the specific yield obtained by the present with values from previous studies.

\subsection{MRS Implementation}

The geophysical method used for the characterization of the Sanon aquifer is MRS. The prospecting strategy adopted, meaning the choice of places where MRS soundings have been implemented takes into account the existing data and the experiments already carried out on the site: drilling lithologs described according to the cuttings, other geophysical measurements and the resulting 2D geological section. It aims to appreciate the spatial variations of MRS water content and pore size in the Sanon experimental site. 
The MRS techniques have been successfully used for characterizing aquifers since 1990's [24]. The major advantage of MRS as compared to other geophysical methods is that with MRS, the groundwater molecules themselves generate the signals that are measured, thus resulting in direct measurement of groundwater [25]. MRS is a method that concerns the hydrogen protons of the water molecule present in the subsoil. Performing MRS consists in modifying the equilibrium state of these protons by circulating in a loop a current oscillating at a given frequency which will induce an excitation magnetic field. MRS is the field scale implementation of the nuclear magnetic resonance method. To carry out a measurement, the nuclei of the hydrogen atoms of water molecules in the subsurface (i.e., protons) are energized with an EM pulse and the signal response of the hydrogen nuclei is measured after the energizing pulse is switched off. The recorded signal of the hydrogen nuclei oscillates at the Larmor frequency $\omega \mathrm{L}$ and has an exponential envelope that decays at time rate $T_{2}{ }^{*}$. This so-named Free Induction Decay (FID) signal is given by Equation (1) [17,19,26].

$$
e(t, q)=E_{0}(q) \cdot \exp \left(-\frac{t}{T_{2}{ }^{*}(q)}\right) \sin \left(\omega_{0} t+\varphi_{0}(q)\right)
$$

where $e(t, q)$ is the envelop of the decaying FID, $E_{0}$ is the amplitude of the signal just after the energizing pulse $q$ has been turned off and $\varphi_{0}$ is the phase shift of the signal.

This relationship can provide three types of information:

- $\quad$ The initial amplitude of the signal $E_{0}$ which is directly related to the number of hydrogen nuclei that participated to signal response and consequently to the quantity of groundwater;

- The decay parameter $T_{2}{ }^{*}$ is related to the mean size of the pores containing water and therefore to a porosity;

- The phase difference between the signal response and the primary current $\varphi_{0}$ is related to the electrical resistivity of the reservoir.

Five (05) MRS were performed on the site. We used the NumisPLUS apparatus from Iris Instruments [27]. The choice of shape of the MRS loop results from a compromise between the desire to obtain a large investigated volume and that to improve the measurement conditions (reduce the electromagnetic noise). The electromagnetic noise represents all the signals that are not of MRS origin but which are still recorded by the NumisPLUS device. They can be of natural origin (fields created by the telluric currents, variations of the field in the magnetosphere) or anthropic (fields created by the lines of electric current, the vehicles, the electric motors). The size of the loop (i.e., the length of the sides) was chosen as large as possible for increasing the amplitude of the MRS signal and the number of stacks was chosen to maximize the signal to noise ratio [19]. The measurements were conducted so as to ensure good data quality, i.e., a high signal-to-noise ratio. In order to understand the spatial variability of the MRS water content, the selected MRS sites are: the ridges north and south (S1CN and S1CS respectively) where the surface runoff is predominant, the mid-slope (S11), the outlet (S8) and the central valley (S1) where recharge is important. In each of the MRS sites, the geology is known from the lithologs description from drilling other geophysical measurement and the resulting 2D geological model. In most of the cases, the MRS were performed around existing monitored observation wells (S1, S11, S1CN, S8) expecting the MRS performed on the south ridge S1CS where no observation well exists. The mean duration of a sounding on the site lasted two days.

\subsection{MRS Data Processing}

The interpretation of the MRS data concerns the initial amplitude of the signal according to the pseudo-depth $\left(E_{0}(q)\right)$ (Figure 3$)$ and the time decay of the signal according to the pseudo-depth $\left(T_{2}^{*}(q)\right)$ (Figure 4). It is essentially based on a phase of data inversion and modelling. The first one consists of matching geophysical data with a terrain model having given properties of water content versus depth $w(z)$ and time decay of the signal versus depth $T_{2}{ }^{*}(z)$. Based on a recent work done by Vouillamoz et al. [19], we use single layer inversions to obtain mean properties of the parameters. In fact, the 
present study does not intend to assess the properties of the fissured and saprolite layers separately because the success and the sustainability of a borehole are controlled by the combined properties of each individual layer. Moreover, the boundary between the two layers is a conceptual boundary, i.e., it is not sharp but rather smooth since the layers resulted from the same weathering processes. Thus, our study focused on average properties of aquifers, i.e., the properties of a single layer which behave as the saprolite and fissured layers together. Using a single layer inversion is also justified by preventing some frequent suppression problems in geophysics [28]. According to the same authors, the single-layer and multi-layer models are equivalent because the products $w \times \Delta z$ of their water content times thickness are about the same. The inversion of the data thus provides a model with the parameters $w, \Delta z$ and $T_{2}{ }^{*}$ for the single layer. The inversion of MRS data can lead to equivalence problems which consist of the fact that two models can produce the same MRS signal; for these two models the product $w \times \Delta z$ is the same. A priori knowledge of one of the factors of this product can help to determine the other. Based on the drilling lithologs we imposed a constraint by fixing the depth of the aquifer bottom (corresponding to the depth at the bottom of the fissured zone) to avoid equivalence problems.

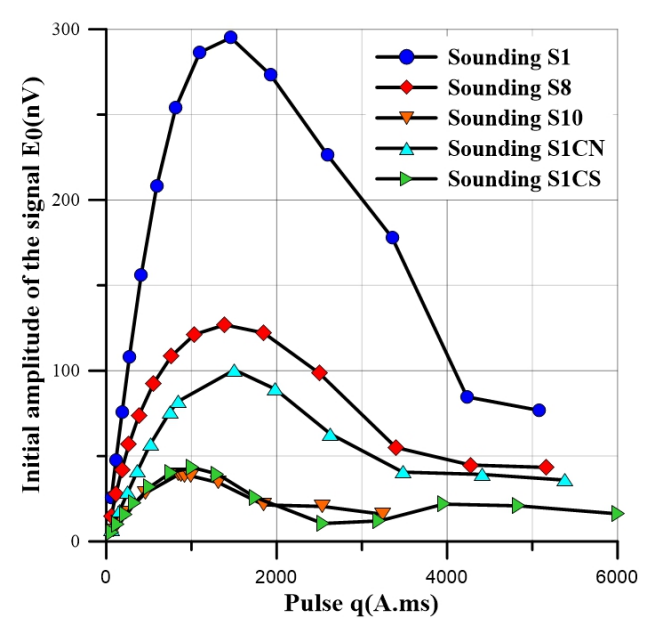

Figure 3. MRS initial amplitude of the signal versus pseudo-depth obtained at MRS sites S1, S8, S11, S1CN and S1CS.

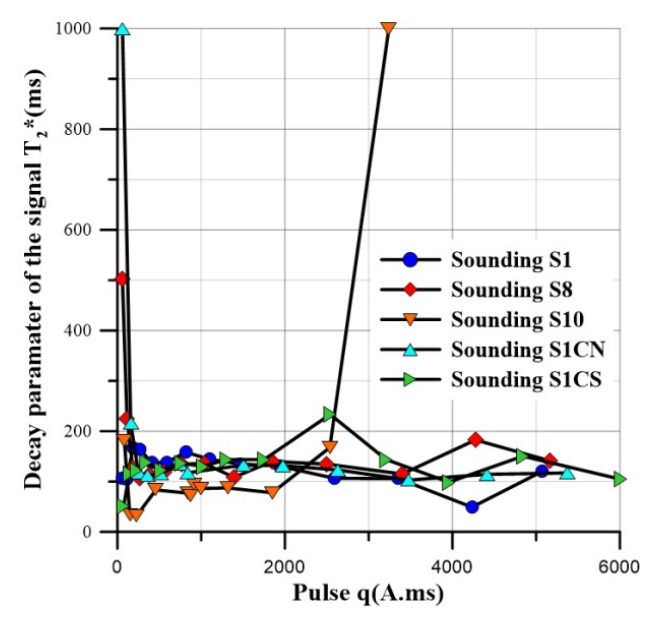

Figure 4. Time decay of the signal versus pseudo-depth recorded at MRS site S1, S8, S11, S1CN, S1CS and showing for the sounding S10, an artefact at pulse 3200 due to a water content which cannot be detectable by the device. 
Prior to any interpretation the quality of the signal must be assessed because it can be disturbed by electromagnetic noise. Indeed, the electromagnetic noise represents all signals which do not originate from MRS but which are recorded by the device. The ratio signal/noise is an indicator used to assess the quality of the data. On the field, the shape of the loop and a procedure of stacking enable to increase the ratio signal/noise [27].

\subsection{Estimation of Groundwater Storage Change}

The change to the groundwater storage $(\Delta S)$ is related to the water level fluctuation $(\Delta h)$ as follows (Equation (2)):

$$
|\Delta S|=S_{y} \times \Delta h
$$

where $S_{y}$ is the specific yield or the quantity of water drains from the aquifer by the gravity force, $\Delta h$ is the water table fluctuation.

The change in groundwater storage can be attributed to recharge, irrigation return flow and groundwater inflow to the basin minus baseflow (groundwater discharge to streams or springs), evapotranspiration from groundwater, pumping and groundwater outflow from the basin. In the following sections, we describe each term of Equation (2) and develop the methodology adopted for their estimation.

\subsubsection{Specific Yield $S_{y}$}

$S_{y}$ represents the volume of water released per unit of area of the aquifer for a unit decrease in the hydraulic head [29]. Precision in its determination is crucial to arrive at a reasonable estimate of recharge. It can be obtained by various methods such as laboratory tests, grain size analysis or pumping tests. In the case of this study, we estimated $S_{y}$ using the relationship established between the $S_{y}$ drainage porosity and the MRS water content (Equation (3)) by Vouillamoz et al. [19] on hard rock formations in Benin.

$$
S_{y}=0.53 \times W_{M R S}+0.007
$$

where $W_{M R S}$ is the MRS water content obtained from the interpretation of MRS performed around observation wells. Substituting $S_{y}$ in Equation (2) with its expression (Equation (3)), Equation (2) becomes:

$$
\Delta S=\left(0.53 \times W_{M R S}+0.007\right) \times \Delta h
$$

\subsubsection{Estimation of Water Table Fluctuation $\Delta h$}

The water-table fluctuation (WTF) method is based on the premise that rises in groundwater levels in unconfined aquifers are due to recharge arriving at the water table. The methods popularity comes from its straightforward use and the general availability of water table data for recharge estimation [30]. This method is most applicable in areas with shallow water tables that display sharp rises and declines following rainfall events. The method should work best for wells that show a relatively rapid water-level rise in relation to the rate that water moves away from the water table. Favourable aspects of the WTF method include its simplicity and ease of use: it can be applied for any shallow well that taps the water table and an abundance of available water-level data exists. The method requires no assumptions on the mechanisms for water movement through the unsaturated zone; hence, the presence of preferential flow paths does not restrict its use [31].

The WTF $\Delta h$ is estimated from hydraulic head measurements from piezometers of the experimental site which are not influenced by water abstraction from pumping boreholes. $\Delta h$ determination in the WTF method is complex. Indeed, despite the assertion on which the method is relied on, not all water table rises in aquifers are attributable to infiltrated water from rainfall [31]. Various phenomenon that are independent from rainfall, can induce water table rise. Examples are given by entrapped air in pores, ocean tides and the earth's crust de-formations and variation in atmospheric pressure [32]. In this study, the change of atmospheric pressure has been taking into 
account due to its great influence, compared with earth tides on water-level fluctuations within wells tapping unconfined aquifers [33]. According to Rahi and Halihan [34]. In the case of a well penetrating an unconfined aquifer, atmospheric changes affect the water level within the well instantaneously, whereas the effects on the aquifer, if present, are delayed due to the presence of the air and other gasses within the unsaturated zone. This time lag created pressure differences between the well and the aquifer which generated flow to and out of the well, hence water-level fluctuations. Regarding the water level measurement in the observation wells, we used automatic leveloggers that measure the water level with an accuracy of $1 \mathrm{~cm}$. The leveloggers measure an absolute pressure. This means that the sensor not only measures the water pressure but also the barometric pressure acting on the surface of the water. If barometric pressure varies, the measured water pressure will also vary, without any change in the water level. In order to correct this influence of barometric pressure, we used automatic barologgers in the different observation wells.

Hourly automatic monitoring of piezometers in the Sanon experimental site between 2014 and 2015 provided data for drawing groundwater hydrographs. Hydrographs interpretation helped in $\Delta h$ determination. At the seasonal scale, $\Delta h(t)$ is the assumed water table fluctuation by differentiating between the maximum piezometric level of the season at time $t$ and the lowest assumed piezometric level [31]. In other words, $\Delta h$ can be estimated either in wet season corresponding to water level rise (recharge), or either in dry season corresponding to water level decline (discharge) according to the desired aim. In a relatively undisturbed system, long-term average recharge and discharge are balanced. The water table fluctuation estimated in wet season $\left(\Delta h^{\text {wet }}\right)$ is usually used for groundwater storage change in terms of renewable groundwater resource as it is the case with the present study. On the other hand, the water table estimated in dry season $\left(\Delta h^{d r y}\right)$ is used for quantifying the drainable groundwater resource. For each observation well, Equation (4) is used for $\Delta S$ computing.

\section{Results and Discussion}

\subsection{Distribution of MRS Water Content $\left(W_{M R S}\right)$ and Signal Time Decay}

The MRS data have good signal-to-noise ratios and show a good fitting with single layer model (Figure 5).

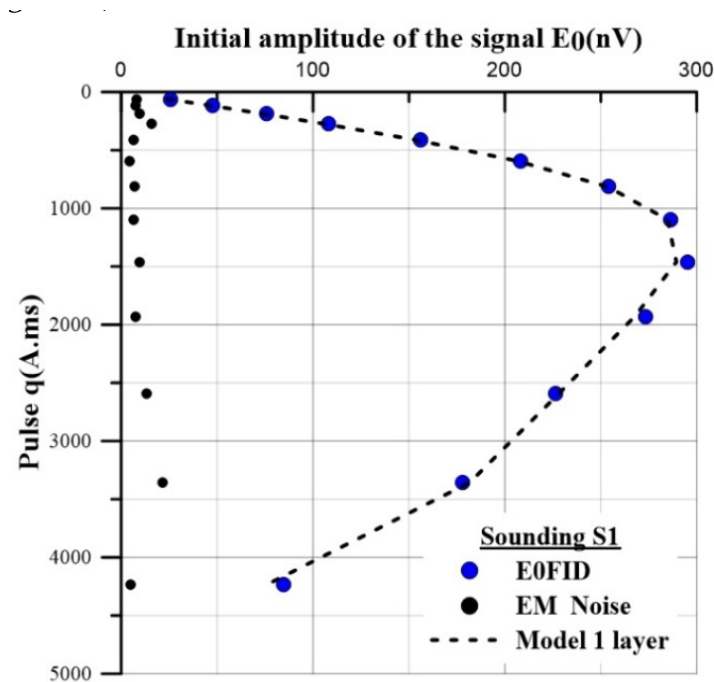

(A)

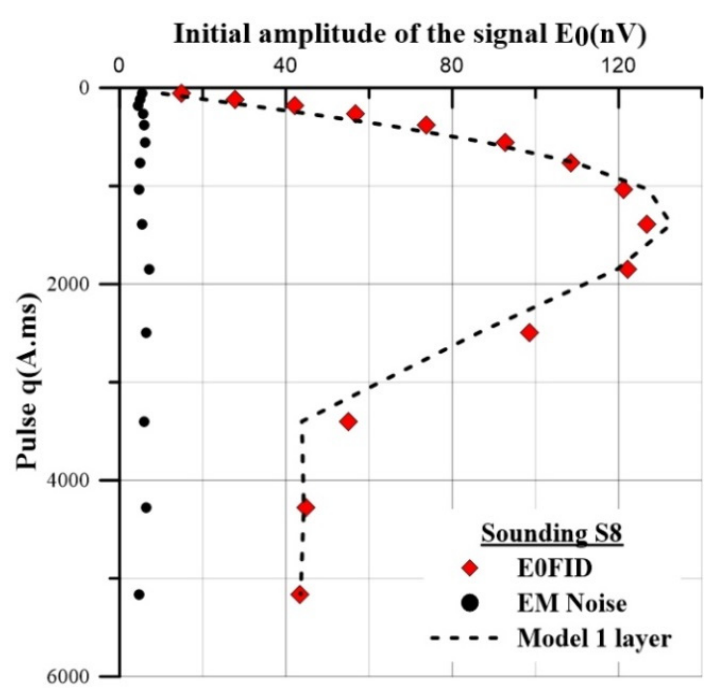

(B)

Figure 5. Cont. 


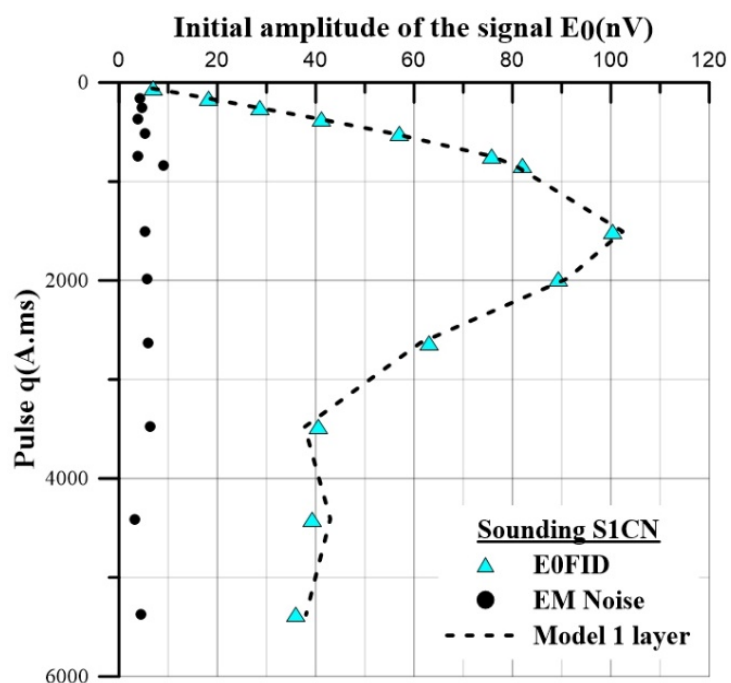

(C)

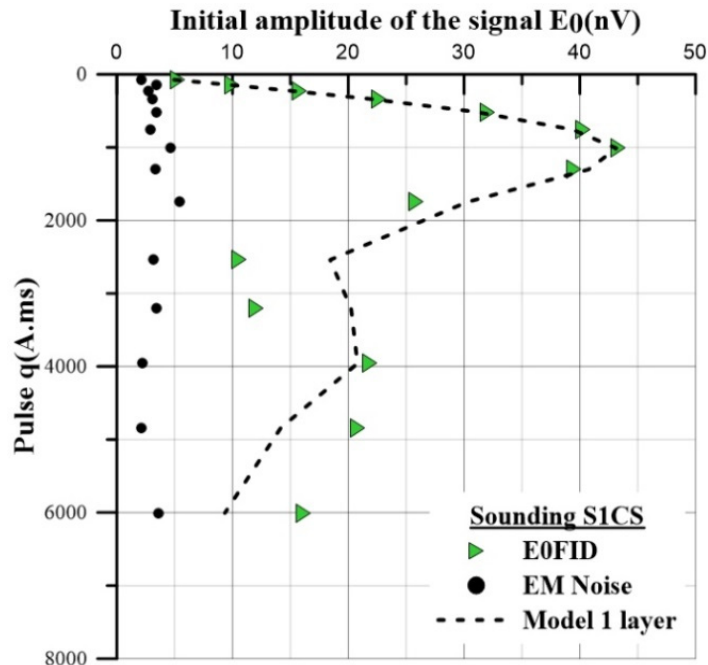

(D)

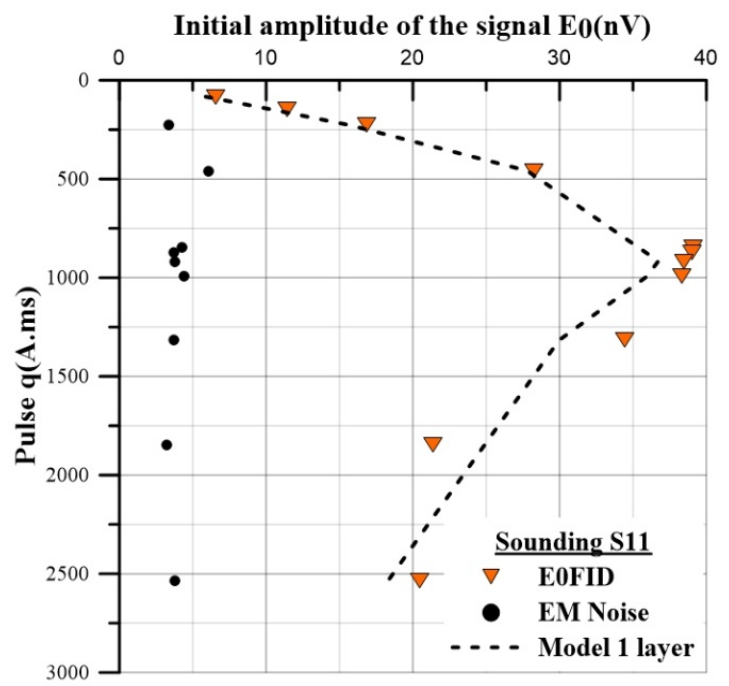

(E)

Figure 5. The initial amplitude of the signal according to the pseudo-depth and fitted single layer model: (A) sounding site S1 in the central valley, (B) sounding site S8 at the catchment outlet, (C) sounding site S1CN at the northern ridge, (D)sounding site S1CS at southern ridge and (E) sounding site $\mathrm{S} 11$ at the mid-slope.

The values of MRS water content obtained therefore reveal that the water content varies from site to site. The table below (Table 1) presents the MRS parameters (MRS water content and time decay), the geometry of the aquifer obtained after interpretation of the survey data. In this table, the water height is calculated as the product of the water $w$ content and the aquifer thickness $\Delta z$.

Table 1. MRS parameters from data inversion.

\begin{tabular}{|c|c|c|c|c|c|c|c|}
\hline $\begin{array}{c}\text { MRS } \\
\text { Location }\end{array}$ & $\begin{array}{c}\text { Water Content } \\
W_{M R S}(\%)\end{array}$ & $\begin{array}{c}\text { Time Decay } \\
T_{2}^{*}(\mathrm{~ms})\end{array}$ & $\begin{array}{l}\text { Aquifer Top } \\
\text { (m) }\end{array}$ & $\begin{array}{c}\text { Aquifer } \\
\text { Thickness } \Delta z(\mathrm{~m})\end{array}$ & $\begin{array}{c}\text { Water Height } \\
\text { w } \Delta z(\mathrm{~m})\end{array}$ & $\begin{array}{c}\text { Ratio } \\
\text { Signal/Noise }\end{array}$ & $\begin{array}{l}\text { RMS } \\
(\mathrm{nV})\end{array}$ \\
\hline S1 & 4.6 & 131.7 & 6 & 52.5 & 2.42 & 9.69 & 8.96 \\
\hline S8 & 2.2 & 126.3 & 6.8 & 41.7 & 1 & 7.17 & 6.42 \\
\hline S10 & 1.3 & 83.7 & 6.8 & 36.2 & 0.47 & 2.29 & 2.24 \\
\hline S1CN & 4.3 & 124.7 & 14.8 & 37.2 & 1.6 & 5.13 & 4.52 \\
\hline S1CS & 1.4 & 132.2 & 8.6 & 41.7 & 0.58 & 3.77 & 5.09 \\
\hline
\end{tabular}


The MRS water content thus obtained by considering a single-layer aquifer (Table 1) vary from site to site. The maximum values are recorded in the central valley around the observation well S1 where the piezometric dome is observed and on the northern ridge around the observation $\mathrm{S} 1 \mathrm{CN}$. The low water content values are recorded around the observation well S10 and at the southern ridge S1CS. These results confirm not only the strongly capacitive role played by the central valley described as a preferential recharge area but also show that the ridges covered by a high thickness of iron crust carapace are not always free of water. The Figure 6 illustrates the water contents averaged over the saturated thickness (single layer model) at S1 and S8. The decay times of the MRS signal $T_{2}{ }^{*}$ vary between 83.7 and $132.2 \mathrm{~ms}$ suggesting that the Sanon aquifer is equivalent to medium-to-fine sands according to [35]. The MRS water content values obtained are less than $5 \%$. These values are in agreement with the other MRS studies carried out in the hard rock [36] and contrast with the water content values obtained in other geological contexts: Boucher et al. [37] obtained an average water content of $13 \%$ for a free sandstone aquifer in Niger.

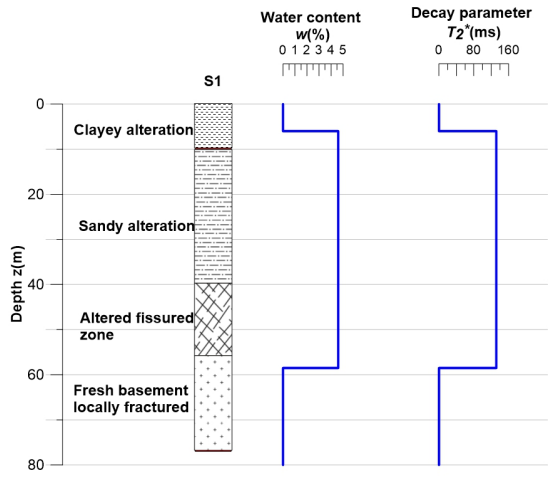

(A)

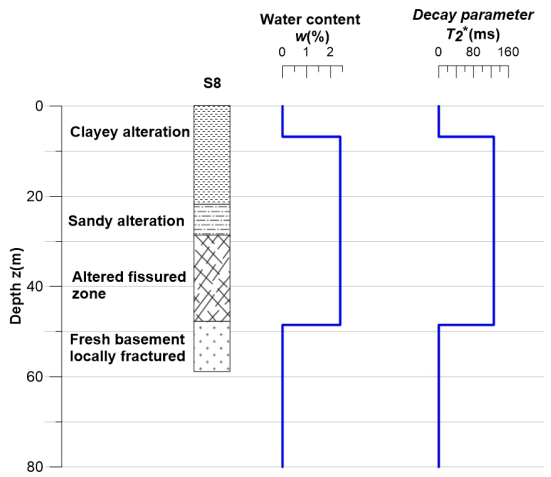

(B)

Figure 6. Lithologs and MRS parameters from data inversion: (A) at the central valley S1 and (B) at the catchment outlet S8.

The analysis from ridge to ridge of the water content and the time decay of the signal as a function of the geometry and the structure of the weathering profile crossing the observation wells S1 and S1CN (Figure 2) reveals that the sounding S1, carried out on migmatite, was conducted on a site with a large thickness of sandy alteration. The water content value obtained around S1 is $4.6 \%$ and localized surely in the saprolite and the weathered fissured zone. It proves the strong storage capacity in the piezometric dome zone described as a preferential zone of recharge [21]. The $2.42 \mathrm{~m}$ of "water level height" is the largest of the entire site confirming once again that the saprolite at this location plays a strong capacitive role.

At the north of the profile, the $\mathrm{S} 1 \mathrm{CN}$ sounding on migmatite was conducted in a clay zone overlaid by an iron crust with a thickness extending nearly $20 \mathrm{~m}$. These surface conditions at this location are more favour to runoff. Yet the value of water content obtained (4.5\%) is close to that obtained in the valley. It suggests that the ridges are not free of water. Such water content is probably related to the proximity of the piezometric dome. The time decay of the MRS signal is $131.7 \mathrm{~ms}$ for the S1 sounding versus $124.7 \mathrm{~ms}$ for the $\mathrm{S} 1 \mathrm{CN}$ sounding. The relatively low value of $T_{2}{ }^{*}$ is undoubtedly influenced by the presence of clay over $23 \mathrm{~m}$.

The S1CS sounding was conducted at a location identified by Soro et al. [22] as a likely intrusion of a conductive medium into a resistant medium. The value of $T_{2}{ }^{*}$ obtained is comparable to that obtained in S1, however, the saprolite extends only about ten meters. One could make the hypothesis of a medium of high porosity at depth. This would be in adequacy with the presence of a probable intrusion, electrically conductive structure. The water content in this place is quite modest with a value of $1.4 \%$. 
The S11 sounding conducted on migmatic basement was not performed on this profile. It is however located nearby. This survey yielded somewhat surprising results. The $T_{2}{ }^{*}$ value of $83.7 \mathrm{~ms}$ differs from all other values obtained on the site. This exception suggests that the measurement has been influenced by electromagnetic noise. Indeed, among all the soundings conducted with square-loop geometries, it has the highest average electromagnetic noise value. The signal-to-noise ratio with a value of 2.94 is also the lowest.

\subsection{Water Level Fluctuation}

The analysis of the water table fluctuation from 2014 to 2016 concerns the monitored observation wells (S1, S8, S11 and S1CN). We will focus mainly on two zones: the central valley (S1 site where a piezometric dome is observed) and the outlet (S8 site) where the lowest piezometric heads were recorded $[20,21]$. Piezometry and rainfall dynamic (Figure 7) during this period has shown rainfall to be the only source of aquifer's recharge once a year with a unique contribution from July to September. The water level rise and decline in the aquifer are under rainfall control. Therefore, water level rise occurs in the period of July to September and correspond to wet season; while water level decline corresponds to dry season period from October to June. It was observed that the aquifer is not responding immediately to the onset of the wet season. A delay instead is observable in the groundwater response to daily precipitation; a delay which can vary from 42 to 45 days. This delay period; i.e., the time-lag, appears to correspond to the duration of top soil humidification from its drying during the preceding season. The delay in groundwater response to first rain events is not simultaneously observable at the central. It varies from the centre of valley to the outlet to the outfall. Indeed, there are approximately three days between the reaction in the centre of the valley and that at the outlet. Various parameters including rainfall depth, number of rain events, water table depth and rainfall spacing can explain the observed situation. The groundwater hydrographs have different amplitudes and response times according to rainfall. In the valley (S1), the water level begins to rise during the second decade of July and last about 2 months (Figure 7A). The peak extends for about a week and is observed between mid-September and mid-October. The water table fluctuation $(\Delta h)$ in the central valley is the largest (4.54 $\mathrm{m}$ in 2015) of the site. At the outlet (Figure 7B), the observation well S8 shows a recharge and a trend (water level rise and decline) almost similar to that observed in the central valley (S1). The water table fluctuation $(\Delta h)$ recorded at the outlet (S8) in 2015 is $2.53 \mathrm{~m}$. Concerning the observation well S11 (Figure 7C), the analysis covered only the period from 29 September 2014 to 18 February 2015. Beyond this, we found that the water level recorded in observation well S11 was influenced by the pumping done in S10. Over this short observation period, we found that the water rise occurs from mid-October to the end of November 2014. The corresponding water table fluctuation $(\Delta \mathrm{h})$ is $2 . \mathrm{m}$. Regarding the $\mathrm{S} 1 \mathrm{CN}$ piezometer, it is located at the northern ridge, water level monitoring started relatively late (November 2015) compared to others. At S1CN site (Figure 7D), the water level rise reached its maximum value in December 2015. This peak is shifted about 3 months from those observed in the central valley and at the outlet.

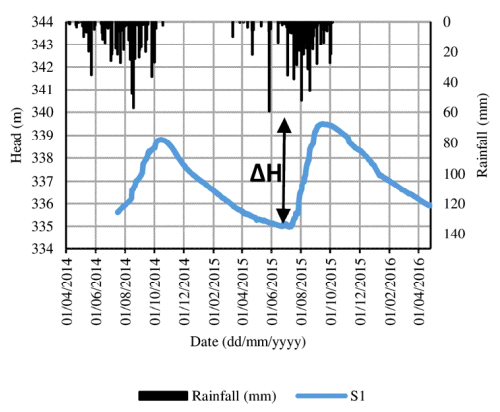

(A)

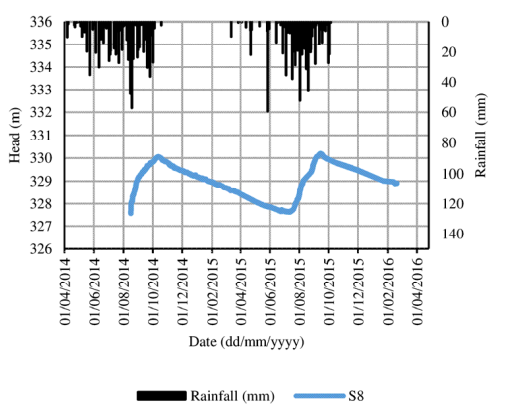

(B)

Figure 7. Cont. 


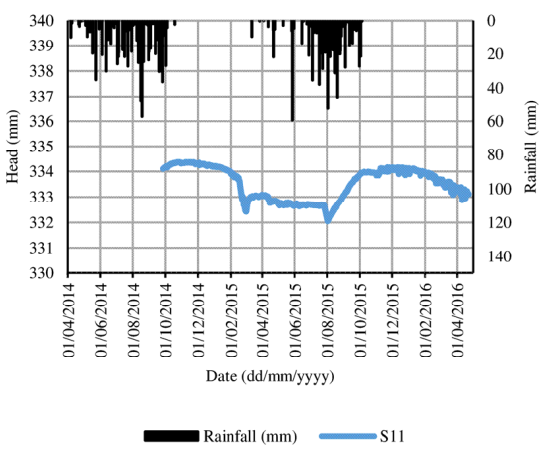

(C)

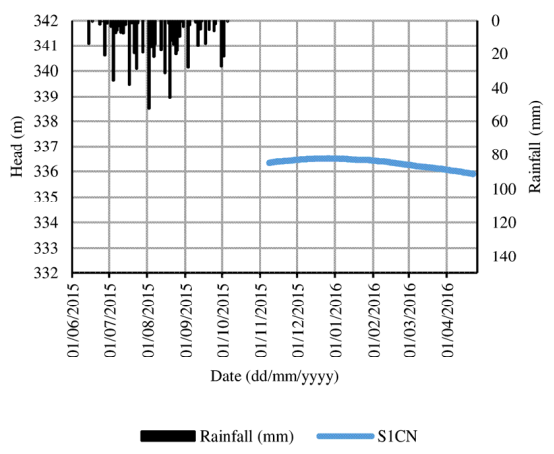

(D)

Figure 7. Groundwater hydrographs and bar graphs of daily rainfall recorded: (A) in the central valley in observation well S1, (B) at the outlet in observation well S8, (C) at the mid-slope in observation well S11 and (D) at the northern ridge in observation well S1CN.

\subsection{Change of Groundwater Storage}

The Table 2 shows the specific yield $\left(S_{y}\right)$ and change of groundwater storage $(\Delta S)$ values. The values $S_{y}$ range from $2.4 \%$ in the central valley to $1.3 \%$ at the outlet (Table 2 ). The changes of groundwater storage are greater in the central valley than at the catchment outlet and correspond to 13.7 and $3.7 \%$ of the annual rainfall, respectively. In the central valley, the change of groundwater storage recorded is of the same order of magnitude as the value of the annual recharge $(10 \%$ of the annual rainfall) estimated by the water balance method [20]. Considering that the change in groundwater storage can be attributed to recharge, irrigation return flow and groundwater inflow to the catchment minus baseflow (groundwater discharge to streams or springs), evapotranspiration from groundwater, pumping and groundwater outflow from the catchment, the groundwater budget can be expressed by Equation (5) [11]. This statement would mean that the parameters of groundwater budget beside the recharge are null or meaningless.

$$
R+R F+Q_{o n}=E T+P G+Q_{o f f}+Q_{b f}+\Delta S
$$

where $R$ is the amount of total groundwater recharge (sum of the direct recharge from the precipitation and the indirect recharge from surface bodies), $R F$ is the irrigation return flow, $Q_{o n}$ and $Q_{o f f}$ are the input and output of groundwater flows respectively, ET is the evapotranspiration from the groundwater, $P G$ signifies the pumping from the aquifer, $Q_{b f}$ is the baseflow (i.e., springs, Qantas and baseflow to the surface bodies such as rivers and lakes) and $\Delta S$ represents the changes in groundwater storage. In fact, in the Sanon catchment, the surface streams are dry most of the time, except a few days after very heavy rainfalls during the wet season; per consequent no baseflow exists.

Table 2. Specific yield and groundwater storage change estimation in Sanon catchment in 2015.

\begin{tabular}{ccccccc}
\hline Sites & $\begin{array}{c}\text { MRS Water } \\
\text { Content (\%) }\end{array}$ & $S_{\boldsymbol{y}}(\mathbf{\%})$ & $\Delta \boldsymbol{h}(\mathbf{m})$ & $\Delta S(\mathbf{m})$ & $\begin{array}{c}\text { Rainfall } \\
(\mathbf{m m})\end{array}$ & $\begin{array}{c}\Delta S / \text { Rainfall } \\
(\mathbf{\%})\end{array}$ \\
\hline $\begin{array}{c}\text { Central } \\
\text { valley (S1) }\end{array}$ & 4.6 & 2.4 & 4.85 & 0.116 & 843 & 13.7 \\
Outlet (S8) & 2.4 & 1.3 & 2.53 & 0.032 & 843 & 3.7 \\
\hline
\end{tabular}

Sanon aquifer is a flat hard-rock aquifer, the regional water table being sub-parallel to regional topography, groundwater flow through the boundaries of the surface watershed are negligible [11]. The investigations we recently conducted on the site have estimated groundwater abstraction (from wells and boreholes) for small-scale irrigation and domestic water needs at $6000 \mathrm{~m}^{3} /$ year or about 
$0.42 \mathrm{~mm}$. In view of this very small amount of withdrawal, the irrigation return flow is negligible. The natural vegetation of the site is of the savanna type with shrub steppe. It is dominated by grasses whose roots do not go beyond $3 \mathrm{~m}$. Concerning evapotranspiration, the depth of water table ( 8 to $11 \mathrm{~m}$ ) in the study area is greater than the limit where evapotranspiration from groundwater can occur, i.e., $5 \mathrm{~m}$ [38]. Regarding the above estimates of the parameters of groundwater budget on Sanon site, the change of groundwater storage corresponds to the annual recharge.

The specific yield estimated from MRS data varies from $2.4 \%$ at the central valley to $1.3 \%$ at the catchment outlet. These values are in agreement with those obtained by Compaore et al. 1997 at the same sites by pumping test and by sample analysis in the laboratory. In fact, the $S_{y}$ values obtained at the central valley by pumping and sample analysis are $2.92 \%$ and $2 \%$ respectively. At the outlet, the specific yield estimated only by sample analysis is $1.8 \%$. On the other hand, the value of $S_{y}$ estimated by MRS in the central valley is lower than that obtained by Koïta et al. [39] by pumping test which is $6 \%$. This difference would probably be related to the conceptual model of the aquifer chosen to interpret the pumping data. Even these values are numerically different, they can be classified in the same order of magnitude. Other studies conducted on similar geological formations and under the same climate conditions in India [11,14] and in Iran [13] have obtained specific yield varying from 0.5 to $2 \%$ and $4 \%$ respectively. The comparison of the specific yield estimated at the Sanon experimental site by MRS with those estimated by pumping tests and by sample analysis in the laboratory, could imply that, in principle, the formula obtained by Vouillamoz et al. [19] in Benin could be transposed to the Sanon site. On the other hand, the existing data do not allow estimating the uncertainties related to its application.

\section{Conclusions}

The geophysical investigations made it possible to characterize the Sanon aquifer from the point of view of the spatial distribution of the water content. The aquifer is equivalent to medium to fine sands depending on the time decay obtained, ranging from 83.7 to $149 \mathrm{~ms}$. The maximum water content and water level is observed in the central valley where a piezometric dome is observed. It is explained by the significant presence of sandy saprolite, the land cover which makes it a preferential recharge area. The northern ridge also yielded significant values of water content. This shows that the ridge does not necessarily lack water despite the predominant runoff which occurs at this location. The change of groundwater storage varies between 3.7 and $13.7 \%$ of the mean annual rainfall. This value corresponds to the aquifer annual recharge because of the small quantities of the other parameters of the groundwater budget. As a result, the combination of the MRS geophysical approach and the water table fluctuation would allow estimating change of groundwater storage.

Acknowledgments: This research is carried out in the framework of the GRIBA project (Groundwater Resources in Basement rocks of Africa), funded by the African Union, the European Union and the Institut de Recherche pour le Développement (IRD) (grant AURG/098/2012). We personally thank Jean-Michel Vouillamoz the project coordinator for supporting us during the project, Fabrice Lawson, PhD student at Abomey Calavi University in Benin.

Author Contributions: Mahamadou Koïta wrote the paper and supervised the data analysis. Hamma Fabien Yonli, Donissongou Dimitri Soro and Emmanuel Dara collected and analyzed all the data. Jean-Michel Vouillamoz is the project coordinator.

Conflicts of Interest: The authors declare no conflict of interest.

\section{References}

1. Giordano, M. Agricultural groundwater use and rural livelihoods in sub-saharan Africa: A first cut assessment. Hydrogeol. J. 2006, 14, 310-318. [CrossRef]

2. Taylor, R.G.; Kouassi, A.D.; Tindimugaya, C. Groundwater and Climate in Africa-A Review. Hydrol. Sci. J. 2009, 54, 655-664. [CrossRef] 
3. Calow, R.C.; Macdonald, A.M.; Nicol, A.L. Ground water security and drought in Africa: Linking availability, access, and demand. Ground Water 2010, 48, 246-256. [CrossRef] [PubMed]

4. MacDonald, A.M.; Bonsor, H.C.; Dochartaigh, B.É.Ó.; Taylor, R.G. Quantitative maps of groundwater resources in Africa. Environ. Res. Lett. 2012, 7, 021003. [CrossRef]

5. Taylor, R.G.; Scanlon, B.; Döll, P.; Rodell, M.; van Beek, R.; Wada, Y.; Longuevergne, L.; Leblanc, M.; Famiglietti, J.S.; Edmunds, M.; et al. Ground water and climate change. Nat. Clim. Chang. 2013, 3, 322-329. [CrossRef]

6. Yadav, G.S.; Singh, S.K. Integrated resistivity surveys for delineation of fractures for groundwater exploration in hard rock areas. J. Appl. Geophys. 2007, 62, 301-312. [CrossRef]

7. Döll, P.; Flörke, M. Global-Scale Estimation of Diffuse Groundwater Recharge. Hydrol. Earth Syst. Sci. Discuss. 2007, 4, 4069-4124. [CrossRef]

8. Howard, K.; Griffith, A. Can the impacts of climate change on groundwater resources be studied without the use of transient models? Hydrol. Sci. J. 2009, 54, 754-764. [CrossRef]

9. Howard, K.W.; Karundu, J. Constraints on the exploitation of basement aquifers in East Africa-Water balance implications and the role of the regolith. J. Hydrol. 1992, 139, 183-196. [CrossRef]

10. Scibek, J.; Allen, D.M.; Cannon, A.J.; Whitfield, P.H. Groundwater-surface water interaction under scenarios of climate change using a high-resolution transient groundwater model. J. Hydrol. 2007, 333, 165-181. [CrossRef]

11. Maréchal, J.C.; Dewandel, B.; Ahmed, S.; Galeazzi, L.; Zaidi, F.K. Combined estimation of specific yield and natural recharge in a semi-arid groundwater basin with irrigated agriculture. J. Hydrol. 2006, 329, 281-293. [CrossRef]

12. Dewandel, B.; Maréchal, J.C.; Bour, O.; Ladouche, B.; Ahmed, S.; Chandra, S.; Pauwels, H. Upscaling and regionalizing hydraulic conductivity and effective porosity at watershed scale in deeply weathered crystalline aquifers. J. Hydrol. 2012, 416, 83-97. [CrossRef]

13. Rezaei, A.; Mohammadi, Z. Annual safe groundwater yield in a semiarid basin using combination of water balance equation and water table fluctuation. J. Afr. Earth Sci. 2017, 134, 241-248. [CrossRef]

14. Dewandel, B.; Caballero, Y.; Perrin, J.; Boisson, A.; Dazin, F.; Ferrant, S.; Chandra, S.; Maréchal, J.-C. A methodology for regionalizing 3-D effective porosity at watershed scale in crystalline aquifers. Hydrol. Process. 2017, 31, 2277-2295. [CrossRef]

15. Kelly, W.E. Geoelectric sounding for estimating aquifer hydraulic conductivity. Ground Water 1977, 15, 420-425. [CrossRef]

16. Perdomo, S.; Ainchil, J.E.; Kruse, E. Hydraulic parameters estimation from well logging resistivity and geoelectrical measurements. J. Appl. Geophys. 2014, 105, 50-58. [CrossRef]

17. Legchenko, A.; Baltassat, J.M.; Beauce, A.; Bernard, J. Nuclear magnetic resonance as a geophysical tool for hydrogeologists. J. Appl. Geophys. 2002, 50, 21-46. [CrossRef]

18. Vouillamoz, J.M. La Caractérisation des Aquifères par une Méthode non Invasive: Les Sondages par Résonance Magnétique Protonique. Ph.D. Thesis, Université Paris Sud-Paris XI, Orsay, France, 2003.

19. Vouillamoz, J.M.; Lawson, F.M.A.; Yalo, N.; Descloitres, M. The use of magnetic resonance sounding for quantifying specific yield and transmissivity in hard rock aquifers: The example of Benin. J. Appl. Geophys. 2014, 107, 16-24. [CrossRef]

20. BRGM-Aquater. Exploitation des Eaux Souterraines en socle Cristallin et Valorisation Agricole: Pilote Expérimental en Milieu Rural Pour les Zones Soudano-Sahéliennes et Sahéliennes; Rapport 33576; BRGM (Bureau de Recherches Géologiques et Minières): Orléans, France, 1991. (In French)

21. Compaore, G.; Lachassagne, P.; Pointet, T.; Travi, Y. Evaluation du stock d'eau des altérites: Expérimentation sur le site granitique de Sanon (Burkina Faso) Hard Rock Hydrosystems (Proceedings of Rabat Symposium S2, May 1997). IAHSPubI 1997, 241, 37-46.

22. Soro, D.D.; Koïta, M.; Biaou, C.A.; Outoumbe, E.; Vouillamoz, J.M.; Yacouba, H.; Guérin, R. Geophysical demonstration of the absence of correlation between lineaments and hydrogeologically usefull fractures: Case study of the Sanon hard rock aquifer (central northern Burkina Faso). J. Afr. Earth Sci. 2017, 129, 842-852. [CrossRef]

23. Dewandel, B.; Lachassagne, P.; Wyns, R.; Maréchal, J.C.; Krishnamurthy, N.S. A generalized 3D geological and hydrogeological conceptual model of granite aquifers controlled by single or multiphase weathering. J. Hydrol. 2006, 330, 260-284. [CrossRef] 
24. Vouillamoz, J.M.; Baltassat, J.M.; Girard, J.F.; Plata, J.; Legchenko, A. Hydrogeological experience in the use of MRS. Bol. Geol. Min. 2007, 118, 385-400.

25. Legchenko, A.; Valla, P. A review of the basic principles for proton magnetic resonance sounding measurements. J. Appl. Geophys. 2002, 50, 3-19. [CrossRef]

26. Hoareau, J. Utilisation D'une Approche Couplée Hydrogéophysique Pour L'étude des Aquifères-Applications aux Contextes de Socle et Côtier Sableux. Ph.D. Thesis, Université Joseph Fourier, Grenoble, France, 2009.

27. Bernard, J. Instruments and field work to measure a Magnetic Rosonance Sounding. Bol. Geol. Min. 2007, $118,459-472$.

28. Legchenko, A. Magnetic Resonance Imaging for Groundwater; John Wiley \& Sons, Inc.: Hoboken, NJ, USA, 2013.

29. Freeze, R.A.; Cherry, J.A. Groundwater, 1st ed.; Prentice-Hall: Upper Saddle River, NJ, USA, 1979; pp. 36-38.

30. Chand, R.; Hodlur, G.K.; Prakash, M.R.; Mondal, N.C.; Singh, V.S. Reliable Natural Recharge Estimates in Granitic Terrain. Curr. Sci. 2005, 88, 821-824.

31. Healy, R.W.; Cook, P.G. Using groundwater levels to estimate recharge. Hydrogeol. J. 2002, 10, 91-109. [CrossRef]

32. Crosbie, R.S.; Binning, P.; Kalma, J.D. A time series approach to inferring groundwater recharge using the water table fluctuation method. Water Resour. Res. 2005, 41, 1-9. [CrossRef]

33. Rahi, K.A. Estimating the Hydraulic Parameters of the Arbuckle-Simpson aquifer by Analysis of Naturally-Induced Stresses. Ph.D. Thesis, Oklahoma State University, Stillwater, OK, USA, 2010.

34. Rahi, K.A.; Halihan, T. Identifying Aquifer Type in Fractured Rock Aquifers using Harmonic Analysis. Ground Water 2013, 51, 76-82. [CrossRef] [PubMed]

35. Schirov, M.; Legchenko, A.; Créer, G. A new direct non-invasive groundwater detection technology for Australia. Explor. Geophys. 1991, 22, 333-338. [CrossRef]

36. Descloitres, M.; Seguis, L.; Wubda, M. Caractérisation des Aquifères sur les Sites Amma Catch au Bénin, Apport de la Résonance Magnétique des Protons. Rapport de mission IRD (23 novembre-10 décembre 2006). 2007. Available online: www.amma-catch.org/IMG/pdf/rapport_rmp_benin_sans_annexes.pdf (accessed on 20 September 2017).

37. Boucher, M.; Fraveau, G.; Descloitres, M.; Vouillamoz, J.-M.; Massuel, S.; Nazoumou, Y.; Cappalaere, B.; Legchencko, A. Contribution of geophysical surveys to groundwater modelling of a porous aquifer in semiarid Niger: An overview. C. R. Geosci. 2009, 341, 800-809. [CrossRef]

38. Ajami, H.; Maddock, T.; Meixner, T.; Hogan, J.F.; Guertin, D.P. RIPGISNET: A GIS Tool for Riparian groundwater evapotranspiration in MODFLOW. Ground Water 2012, 50, 154-158. [CrossRef] [PubMed]

39. Koïta, M.; Yonli, H.F.; Soro, D.D.; Dara, A.E.; Vouillamoz, J.M. Taking into Account the Role of the Weathering Profile in Determining Hydrodynamic Properties of Hard Rock Aquifers. Geosciences 2017, 7, 89. [CrossRef] 